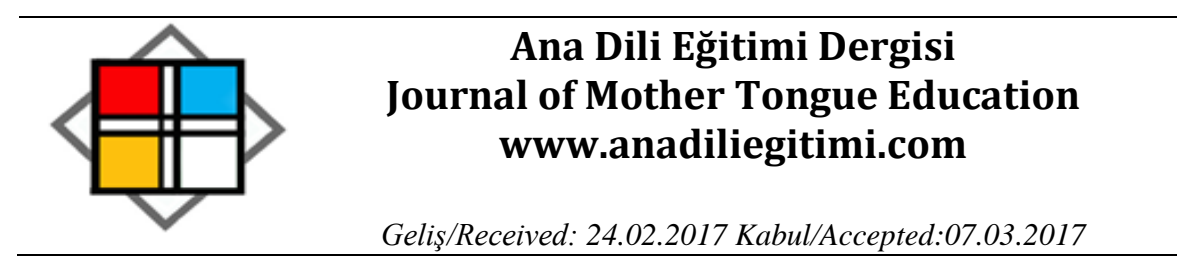

\title{
Sınıf Öğretmenlerinin Türkçe Dersi Öğretim Programına Yönelik Görüşleri
}

\author{
KasIm YILDIRIM* \\ Esma KANDEMIR ${ }^{* *}$ \\ Zehra ÇINAR ${ }^{* * *}$
}

Öz

Bu araştırmanın amacı sınıf öğretmenlerinin 2016-2017 eğitim ve öğretim yılında uygulamaya konulan Türkçe Dersi Öğretim Programına yönelik görüşlerini incelemektir. Bu genel amaç doğrultusunda toplam 78 sınıf öğretmeni çalışmaya dâhil edilmiştir. Araştırmada veri toplama aracı olarak açık ve kapalı uçlu sorulardan oluşan anket formu kullanılmıştır. Elde edilen veriler üzerinde betimsel analizler gerçekleştirilmiştir. Araştırma verilerinden elde edilen bulgular çalışmaya katılan öğretmenlerin çoğunun yeni programı okumadığını dolayısı ile öğretmenlerin yeni programa yönelik farkındalıklarının yetersiz olduğu sonuçlarını ortaya koymuştur. Buna ek olarak yeni öğretim programını inceleyen öğretmenlerin yapılan değişiklikleri yeterli gördüğü ancak yapılması gereken değişikliklerle ilgili beklentilerinin tam olarak karşılanmadığı yönünde görüşler ileri sürdükleri saptanmıştır. Araştırmadan elde edilen bulgular ilgili literatür bağlamında tartışılmış ve gerekli önerilerde bulunulmuştur.

Anahtar Kelimeler: Sınıf öğretmenleri, öğretmen görüşleri, Türkçe Dersi Öğretim Programı

\section{Elementary School Classroom Teachers' Views on the new Turkish Language Arts \\ Curriculum}

\begin{abstract}
The purpose of this study was to investigate elementary school classroom teachers' views on the new Turkish Language Arts Curriculum which took effect in the 2016-217 academic year. To that end, a total of 78 elementary school classroom teachers were included in the study. As the data collection instrument, a questionnaire, which included open-ended and closed questions, was used in the study. Descriptive analysis procedures were employed to analyze the data. The findings showed that most of the teachers in the study had not read the new curriculum, and, therefore, their awareness regarding the new curriculum was inadequate. The findings also revealed that while the teachers who had examined the new curriculum were satisfied with the changes made in the new curriculum, they expressed the opinion that their expectations about the changes that had to be made were not fully met. The findings of the study were discussed in the light of the related literature, and necessary recommendations were made.
\end{abstract}

Keywords: Elementary school classroom teachers, Teacher views, Turkish Language Arts Curriculum

\footnotetext{
* Muğla Sitkı Koçman Üniversitesi, kasimyildirim@mu.edu.tr

** Muğla Sıtkı Koçman Üniversitesi, kndmerese93@gmail.com

*** Muğla Sıtkı Koçman Üniversitesi, cinarzehra11@gmail.com
} 


\section{Giriş}

Bilginin kümülatif ve kolektif eylemlerin bir sonucu olduğu iddiası birçok ampirik, teorik ve uygulamalı çalışmada ifade edilmektedir. Dolayısı ile bu çalışmanın da ortaya koyduğu tüm bulguların da öğretmenlerin öğretim programları konusundaki düşünceleri ve uygulamaları ile ilgili bilgi havuzuna katkı sağlayacağı düşünülmektedir. Bu araştırmada öğretmenlerin yeni Türkçe Öğretim Programına yönelik görüşleri incelenmiş ve elde edilen bulgular ilgili bilimsel literatür bağlamında tartışımıştır. Sonrasında ise ihtiyaç duyulan noktalarda gerekli önerilerde bulunulmuştur.

Toplumsal dönüşümler değerlerde, yaşam örüntülerinde ve kurallarda birçok değişikliğe sebebiyet vermektedir. Toplumun kendisindeki bu değişimler, okullardan ve öğretmenlerden beklenilenleri de değiştirmektedir. Bu bağlamda öğretmenlerin ve okulların ihtiyaç duyulan becerileri ve yeterlilikleri öğrencilere kazandırması gerektirmektedir. Örneğin bilgi toplumu olmaya yönelik gerçekleşen değişim, öğretim yöntemlerinde ve öğretim programlarında da güncellemeyi gerektirmektedir. Dolayısı ile öğretim programlarıyla ilgili gerçekleştirilen çalışmalar, bu değişime ayak uyduracak ve yeni toplumsal dönüşümün beklentilerini karşılayacak bireylerin yetiştirilebilmesine katkı sağlamayı amaçlamaktadır (Pintó, 2005).

Özellikle öğretmenlere sürekli olarak öğretim süreçlerini bireyselleştirmeleri yani bireyselleştirilmiş öğretim süreçlerini benimsemeleri noktasında tavsiyelerde bulunulur. Maalesef bu öneriler yapılırken öğretmenlerin çalıştığı şartlar pekte göz önünde bulundurulmaz. Yapılandırmacı kuram üzerine temellendirilmiş reformist pedagojiler, öğrenci ilgileri üzerinde önemle durmasına rağmen bu noktada öğretmen eğitimi ve öğretim programlarının geliştirilme süreçlerinin göz ardı edildiği görülmektedir. Dolayısı ile ortaya konulan yeni programlar ve yöntemler beraberinde birçok problemi de getirmektedir. Eğer öğretmenler uygulamaya konulan programı anlamakta problem yaşıyorlarsa yenilenen programın başarıya ulaşması güçleşmektedir. Uygulamaya konulacak yeni programlarla ilgili mesleki gelişim seminerlerinin düzenlenmesi, öğretmenlerin program geliştirme süreçlerine dâhil edilmesi ve öğretmenlerin yeni programa ilişkin olarak görüşlerinin alınması öğretim programlarının uygulanabilirliği, anlaşılması ve başarısı açısından önem arz etmektedir (Cheung ve Wong, 2002).

Öğretmenlerden beklenen temel yeterliliklerden biri de öğrencilerin ihtiyaçlarını karşılayacak ve onların bireysel ihtiyaçlarını göz önünde bulunduracak anlamlı öğrenme ortamları oluşturmalarıdır. Öğretmenlerin bu beklentileri karşılayabilmeleri için onlara yardımcı olacak öğretim programlarının en iyi şekilde yapılandırılması gerekmektedir. Öğretmen öğrenmesi, birinin bilgisini geliştirmeyi ve bilgisini yeni bağlamlara entegre etmesini, öğretme ve öğrenmeyi, bilgiyi öğretimsel kararlar vermede kullanmayı, uygulama süreçlerine aktif katılmayı içermektedir. Öğretmen öğrenmesi, onun uygulamalarının bir parçasıdır. Bu uygulamaların ve öğretmen öğrenmesinin temel dayanaklarından 


\section{Sınıf Öğretmenlerinin Türkçe Dersi Öğretim Programına Yönelik Görüşleri}

biri de öğretim programlarıdır. Öğretmenin programı kullanması ve ondan öğrenmesi sadece hazırlanan öğretim programının içeriğine bağlı değil aynı zamanda öğretmenin öğretim programındaki hangi etkinliklere daha fala entegre olduğuna, hangi içeriği okuduğuna veya hangileri ile ilgilenmediğine, öğretmenin bilgisine ve inançlarına ve öğretmenin programa yönelik eğilimlerine bağlıdır (Davis ve Krajcik, 2005).

Öğretim programına yönelik öğretmen görüşleri ve inançları programın etkili bir şekilde uygulamaya konmasında oldukça önemli bir rol oynamaktadır. Eğitim sürecinde yer alan her bir paydaşın bir dizi inançla eğitim sürecine entegre olduğu göz önüne alındığında bunun en iyi örneklerinden birini de öğretmenlerin uygulanan öğretim programlarına yönelik inançları ve görüşleri gösterilebilir (Cornett, 1990).

Okullarda öğretmenlerin uygulanan öğretim programlarının nasıl yapılandırılması gerektiğine yönelik farklı inançlara sahip olduklarını söylemek mümkündür. Öğretim programlarının uygulanmasına yönelik gerçekleştirilen oryantasyon çalışmaları öğretmenlerin öğretim programları ve kendi sınıf içi uygulamaları konusunda ne düşündüklerini analiz etmek açısından oldukça önemlidir. Öğretmenlerin bu inançları ve ilgili öğretim programına ilişkin görüşleri aslında uygulama sürecinin öğretmenler tarafından nasıl yönlendirebileceğine de ışık tutmaktadır (Jenkins, 2009). Miller ve Seller (1985, akt. Cornet, 1990) tarafından da ifade edildiği gibi öğretmenlerin ortaya konulan programı etkili bir şekilde uygulamalarını etkileyen en önemli faktörlerden biri de kendi uygulamaları ve inançlarıdır.

Türkiye'de de bu bağlamda öğretim programları ile ilgili çalışmalar gerçekleştirilmiştir. Bu araştırmanın da kapsamını oluşturan Türkçe Öğretim Programı ile ilgili bizi dizi çalışma yapılandırılmış ve yeni program 2005 yılı itibari ile okullarda uygulamaya konulmuştur. Bunu takip eden süreçte toplumsal ihtiyaçları ve beklentileri karşılamak amacı ile uygulamadaki Türkçe Öğretim Programı yeniden güncellenerek 2015 yılında yeniden öğretmenlerin kullanımına açılmıştır ve şu anda bu program da yeniden yapılandırılmış ve Talip ve Terbiye Kurulu Başkanlığının internet sitesinde askıya çıkartılarak eğitimcilerin görüş ve önerilerine sunulmuştur. Bir sonraki aşamada gelen görüş ve öneriler göz önünde bulundurulup gerekli düzeltmeler yapıldıktan sonra öğretmenlerin hizmetine sunulacaktır (http://ttkb.meb.gov.tr/www/ogretim-programlari/icerik/72).

Ülkemizde ilgili bilimsel literatür incelendiğinde Türkçe Öğretim Programına yönelik farklı araştırmalara rastlanılmaktadır. Örneğin Çoşkun ve Taş (2008) tarafından yapılan çalışmada ders kitaplarına metin seçimi açısından Türkçe Öğretim Programları değerlendirilmiştir. Güven (2011) tarafından yapılan çalışmada 2005 yılında uygulamaya konulan ikinci kademe Türkçe Öğretim Programına yönelik öğretmen görüşleri değerlendirilmiştir. Kırmızı ve Akkaya (2009) tarafından gerçekleştirilen çalışmada Türkçe Dersi Öğretim Programında yaşanan sıkıntılar bağlamında öğretmen 
görüşleri analiz edilmiştir. Gömleksiz, Sinan ve Demir (2010) gerçekleştirdikleri araştırmada 2005 programındaki yazma öğrenme alanın etkililiğini öğretmen görüşleri doğrultusunda değerlendirmişlerdir. Korkmaz (2006) tarafında yapılan çalışmada 2005 Türkçe Dersi Öğretim Programındaki ilk okuma ve yazma öğretim süreci öğretmen görüşleriyle ilişkili olarak değerlendirilmiştir. Melanlıoğlu (2008) tarafından gerçekleştirilen araştırmada günümüze kadar yapılan, buna 2005 programı da dâhil, Türkçe öğretim Programları kültür aktarımı açısından değerlendirilmiştir. Karadağ (2012) tarafından gerçekleştirilen çalışmada 2005 Türkçe Dersi Öğretim Programı anlama becerileri açısından incelenmiştir. Durukan (2013) tarafından yapılan çalışmada Türkçe Öğretim Programı kazanımları öğretmenlerin görüşleri doğrultusunda analiz edilmiştir. Yine Güzel ve Karadağ (2013) tarafından yapılan çalışmada anlatma becerileri açısından Türkçe Dersi Öğretim Programı değerlendirilmiştir. Şahin'inin (2007) yaptığı araştırmada 2005 Türkçe Dersi Öğretim Programı genel hatları ile incelenmiştir.

Görüldüğü üzere 2005 yılında uygulamaya sokulan ve 2009 yılında tekrar revize edilen Türkçe Dersi Öğretim Programı ile ilgili farklı araştırmalar gerçekleştirilmiş ve bu araştırmalarda hem öğretmen görüşleri bağlamında değerlendirmeler gerçekleştirilmiş hem de güncel gelişmeler bağlamında program genel hatlarıyla karşılaştırmalı olarak incelenmiştir. Ancak günümüze kadar olan çalışmalar göz önünde bulundurulduğunda 2016-2017 eğitim ve öğretim yılından itibaren 1 ve 5. sınıflardan itibaren kademeli olarak uygulamaya konulan yeni Türkçe Dersi Öğretim Programı ile ilgili uygulayıcıların değerlendirmelerini göz önünde bulunduran bir araştırmaya rastlanılmamıştır. Yapılan bu araştırmanın yeni programı öğretmen görüşleri doğrultusunda değerlendiren ilk çalışmalardan birisi olması nedeni ile önemli olduğu düşünülmektedir. Aynı zamanda daha öncede ifade edildiği üzere öğretim programlarına yönelik öğretmen görüşlerinin ve inançlarının göz önünde bulundurulması, daha nitelikli ve toplumsal intiyaçları karşılayan programlarının geliştirebilmesine hem de bu içeriğe uygun bireylerin yetiştirilebilmesine katkı sağlayabilecektir. Bu anlamda araştırmanın bu ihtiyaca da bir nebze de olsa katkı sunması beklenmektedir. Bu doğrultuda araştırmanın genel amacı sınıf öğretmenlerinin görüşleri doğrultusunda Türkçe Dersi (1-8. Sınıflar) Öğretim Programını değerlendirmektir. Bu genel amaç doğrultusunda aşağıdaki sorulara cevaplar aranmıştır:

1. Öğretmenlerin 2005 Türkçe Dersi Öğretim Programına yönelik farkındalıkları ne düzeydedir?

2. Öğretmenlerin 2016-2017 eğitim öğretim yılında uygulamaya konulan Türkçe Dersi Öğretim Programına yönelik farkındalıkları ne düzeydedir?

3. Yeni Türkçe Dersi Öğretim Programı öğretmenlerin beklentilerini ne ölçüde karşılamaktadır? 


\section{Sınıf Öğretmenlerinin Türkçe Dersi Öğretim Programına Yönelik Görüşleri}

\section{Yöntem}

Bu araştırmada sınıf öğretmenlerinin Yenilenen Türkçe Dersi (1-8. Sınıflar) Öğretim Programına yönelik görüşleri betimlenmiştir. Bu bağlamda araştırma betimsel bir durum saptaması niteliğindedir. Kullanılan bu yöntemle öğretmenlerin yenilenen programa yönelik görüşlerinin belirlenmesi ve betimlenmesi amaçlanmıştır. Seçilen bu yöntemle araştırmanın amacının ve ifade edilen problemin en iyi şekilde açıklanacağı ve böylelikle araştırmacılar tarafından öğretmenlerin durumlarının daha doğru bir şekilde ortaya konulacağı düşünülmüştür.

\section{Çalışma Grubu}

Araştırmanın çalışma grubunu Muğla, İzmir ve Manisa illerinde görev yapan toplam 78 sınıf öğretmeni oluşturmuştur. Araştırmada kolay ulaşılabilir örnekleme yönteminden faydalanılmıştır. Bu örneklem tekniğinde amaç uygun ve gönüllü olan katılımcıları araştırmaya dâhil etmektir (Creswell, 2005). Çalışma, araştırmacıların (ikinci, üçüncü ve dördüncü yazar) öğretmenlik yaptığı illerde (Muğla, İzmir ve Manisa) gerçekleştirilmiştir. Böylelikle kendi okullarında veya yakın çevrelerinde tanıdıkları, bildikleri ve araştırmaya katılmaya gönüllü öğretmenler araştırma sürecine dâhil edilmiş ve araştırmanın amacına uygun olacak veriler bu öğretmenlerden toplanmıştır. Araştırma katılımcılarının 51'ini kadın, 27'sini ise erkek öğretmenler oluşturmuştur. Öğretmenlerin yaşları 22 ile 61 arasında değişmiştir (Kadın $X=35.41$, SS=11.65; Erkek $X=36.04$, $S S=11.60$ ). Araştırmaya katılan öğretmenlerin 27'sinin birinci sınıf, 17'sinin ikinci sınıf, 14'ünün üçüncü sınıf ve 20'sinin de dördüncü sınıf okuttuğu anlaşılmıştır. Öğretmenlerin mesleki deneyimleri 1 ile 37 yıl arasında değişmiştir (Kadın $X=12.59$, $S S=11.18$; Erkek $X=13.15, S S=11.92)$. Katılımcıların 3'ünü köy yerleşim alanında görev yapan öğretmenler, $58^{\prime}$ ini ilçe merkezinde ve 17 'sinin ise şehir merkezinde görev yapan öğretmenler oluşturmuştur. Öğretmenlerin 70'inin Eğitim Fakültesi lisans, 8'inin ise Eğitim Enstitüsü ön lisans mezunları olduğu anlaşıımıştır.

\section{Ölçme Aracı}

Çalışmada araştırmacılar tarafından geliştirilen kapalı ve açık uçlu sorulardan oluşmuş anket formu kullanılmıştır. Anketin geliştirilmesi sürecinde ilgili literatür incelenmiş ve elde edilen bilgiler doğrultusunda hazırlanan sorularla taslak bir form oluşturulmuştur. Oluşturulan taslak form, araştırmacıların da dâhil olduğu uzmanlar tarafından incelenmiş; soruların ölçülmek isteneni ölçme, araştırmanın amacına hizmet etme, anlaşııma, sıralanma ve tasarım açısından uygunluğu noktasında görüş alışverişinde bulunulmuştur. Daha sonra hazırlanan taslak form çalışma grubun dışındaki öğretmenlerle tartışılarak anlaşılırlık ve tasarım açısından yeniden düzenlenmiştir. Anket formu iki bölümden oluşmuştur. ìlk bölümde katılımcıların demografik özelliklerine ilişkin değişkenler yer almıştır. Bu bölümdeki sorularla katılımcıların cinsiyet, yaş, öğretim yaptığı sınıf düzeyi, mesleki 
deneyimi, görev yaptığı okulun bulunduğu yer, görev yaptığı il, mezun olduğu bölüm ve mezun olduğu üniversite değişkenlerine ilişkin veriler toplanmıştır. Anketin ikinci bölümündeki sorularla sınıf öğretmenlerinin eski ve yeni Türkçe Öğretim Programlarına ilişkin görüşleriyle ilgili veriler toplanmıştır. Bu bölümdeki sorular kapsamında öğretmenlerin eski programın eksikliklerine, güçlü ve zayıf yönlerine, yeni programın içeriği ve yapısına, yeni programdaki öğrenme alanlarına, ses temelli cümle yöntemi ve bitişik eğik el yazıya ilişkin görüşlere yönelik sorular yer almıştır. Bu bağlamda anketin ikinci bölümünde toplam 13 kapalı ve açık uçlu soru yer almıştır.

\section{Veri Toplama Süreci}

Daha önce de ifade edildiği gibi araştırmanın katılımcılarını sınıf öğretmenleri oluşturmuştur. Araştırmacılardan üçü (ikinci, üçüncü ve dördüncü yazarlar) öğretmen olarak görev yaptıkları illerde araştırmaya katılmaya gönüllü sınıf öğretmenlerinden verileri toplamışlardır. Verileri toplama süreci başlamadan önce araştırmacıların görev yaptıkları illerdeki ilgili MEB birimlerinden çalışmanın yapılabilirliğine ilişkin izinler alınmıştır. Öğretmen olarak görev yapan araştırmacılar vasıtası ile kendi okullarında veya kendi okullarına yakın yerlerde görev yapan sınıf öğretmenlere ulaşıımış, gerçekleştirilecek çalışmanın amacı kendilerine ifade edilmiş ve araştırmaya katılmaya istekli ve gönüllü öğretmemelerden gönüllü katılım izin onayları alındıktan sonra anket formları kendilerine verilmiştir. Sınıf öğretmenlerine anket formlarını doldurmaları için yeterince zaman verilmiş ve sonrasında kendilerine tekrar ulaşılarak anket formları toplanmıştır. Anketler toplandıktan sonra elde edilen veriler üzerinde araştırma sorularına cevap olacak analizler gerçekleştirilmiştir.

\section{Araştırmacıların Araştırma Sürecindeki Rolü}

Araştırmacılardan üçü (ikinci, üçüncü ve dördüncü yazarlar) veri toplama sürecinin tüm aşamalarında görev almış ve sürecin olabildiğince araştırma amacına uygun olarak gerçekleşmesini sağlamışlardır. Sonrasında ise çalışmanın diğer bir araştırmacısı ise (ilk yazar) raporlaştırma sürecini tamamlamıştır.

\section{Araştırmanın Etik İçeriği}

Araştırma süreci, araştırmacıların kişisel yargıları doğrultusunda kesinlikle yönlendirilmemiştir. Her bir katılımcı araştırmanın içeriği konusunda bilgilendirilmiş ve çalışmaya kendi istekleri doğrultusunda katıldıklarına dair "bilgilendirme izin formları" alınmıştır. Yine katılımcılara elde edilecek verilerin raporlaştırılmasında ve bu verilerle ilgili olarak yapılacak bilimsel çalışmalarda kendi kimliklerini ortaya çıkaracak hiçbir bilginin kullanılmayacağının garantisi verilmiştir. Talep ettikleri takdirde kendileri ile ilgili verinin çalışma sürecinden çıkarılabileceği ifade edilmiştir. Aynı zamanda istedikleri an çalışmadan ayrılabilecekleri açıklanmıştır. Yine katılımcılara kendileriyle ilgili oluşabilecek 


\section{Sınıf Öğretmenlerinin Türkçe Dersi Öğretim Programına Yönelik Görüşleri}

herhangi bir olumsuz durumda araştırmacılar olarak tüm yasal yükümlülüklerin kabul edileceği belirtilmiştir.

\section{Kayıt ve Kopyalama}

Öncelikli olarak öğretmen adaylarının anket formalarındaki açık uçlu sorulara vermiş oldukları cevaplar WORD ortamına aktarılmış ve aynı soru başlıkları altındaki tüm öğretmen adaylarının verdiği cevaplar bir araya getirilmiştir. Daha sonraki aşamada alınan tüm kayıtlar gözden geçirilmiş ve bu kayıtlar daha da detaylandırılarak uygun oldukları analiz sürecine sokulmuştur.

\section{Verilerin Analizi}

Açık uçlu sorudan elde edilen veriler öncelikli olarak her bir soru başlığı altında bilgisayarda Word ortamına aktarılmış ve her bir araştırmacı tarafından ayrı ayrı analiz edilmiştir. Daha sonra ulaşılan kodlamalar karşılaştırılmıştır. Görüş farklılıklarının olduğu durumlarda sonuçlar birlikte yeniden değerlendirilmiş ve uzlaşma sağlanmıştır. Elde edilen kodlar tekrarlanma sıklıkları doğrultusunda ilgili oldukları soru başlığı altında tablolaştırılarak sunulmuştur. Tablolardaki frekans değerleri kişi sayısını değil, yapılan kodlamanın kaç kişi tarafından ifade edildiğini göstermiştir.

\section{Araştırmacıların Bakış Açıları}

Bu bilimsel çalışmanın araştırmacıları, öğretim programlarının etkililiğini sağlayan en önemli değişkenlerden biri olarak onun uygulayıcıları olan öğretmenleri görmekte ve öğretmenlerin öğretim programlarına yönelik farkındalık düzeylerinin onların sınıf içi öğretim süreçlerini olumlu ve olumsuz yönde etkileyecek faktörlerden biri olarak düşünmektedirler. Araştırmacıların bu bakış açısı araştırmanın geneline hâkim olmuş ve araştırmanın raporlaştırma sürecini yönlendirmiştir. Aynı zamanda araştırmacılardan birinin Yeni Türkçe Öğretim Programının geliştirilme çalışmalarında yer alması, katılımcılardan elde edilen bulguların raporlaştırma sürecini etkilemiştir.

\section{Araştırmanın Geçerliliği ve Güvenirliliği}

Özellikle nitel paradigma mantığının benimsendiği çalışmalarda araştırma bulgularının sayısal niceliklerle de desteklenmesi araştırmaların kalitesini artırmada kullanılan önemli yollardan biridir (Yıldırım, 2010). Bu araştırmada da elde edilen veriler sayısal değerlerle desteklenmiştir. Araştırmada elde edilen veriler çalışmadaki araştırmacılar tarafından değerlendirilmiş ve sürekli yapılan karşılaştırmalarla en doğru yargılara ulaşılmaya çalışılıışır. Daha sonra veriler araştırmanın mantığını bilen, eğitim programları alanında çalışan bağımsız bir kodlayıcıya verilmiş ve kendisinden verileri değerlendirmesi istenmiştir. Daha sonra bağımsız araştırmacının ulaştığı değerlendirmeler ile araştırmacıların ulaşmış oldukları sonuçlar karşılaştırımış ve var olan uyuşmazlıklar giderilmeye çalışımıştır. Araştırmacıların ve bağımsız kodlayıcının ikilemde kaldığı durumlar tekrar gözden 
geçirilmiş ve ortak bir fikir birliğine varılıncaya kadar gerekli düzeltmeler gerçekleştirilmiştir. Yapılan bu araştırmanın transfer edilebilirliğini artırmak için anlaşıır ve detaylı betimlemelere yer verilmiş; veri toplama süreci, katılımcıların özellikleri, nasıl seçildikleri ve veri analiz süreci detaylı bir şekilde araştırmada sunulmuştur. Bu şekilde araştırmanın transfer edilebilirliğine katkı sağlanmıştır (Creswell ve Miller, 2000). Bu şekilde yapılacak benzer çalışmalara ayrıntılı betimlemeler vasıtası ile yol gösterilmiştir. Bu araştırmada çalışmanın geçerliğini ve güvenirliğini artırmak için izlenilen yollardan biri de ulaşılan sonuçların çalışmadaki katılımcılardan bazılarına gösterilmesi ve ulaşılan sonuçlar hakkında onların görüşlerinin alınmasıdır. Böylelikle elde edilen bulgulara yönelik katıımcılardan dönütler alınmış ve bu şekilde araştırmacılardan kaynaklanabilecek yanlılıklar en aza indirgenmeye çalışımıştır. Elde edilen bulguların inandırıcılığını artırmak amacı ile katılımcıların açık uçlu soruya ilişkin belirtmiş oldukları görüşlerden örnek alıntılara yer verilmiştir. Bu alıntılar yapılırken araştırmaya yanlılık katacak görüşler değil, verilen cevapların genelini yansıtacak görüşlerle ilgili örneklerden alıntılar yapılmıştır.

\section{Bulgular}

Araştırma kapsamında katılımcılara öncelikle 2004 yılında kabul edilen Türkçe Dersi Öğretim Programının eksikliklerinin olup olmadığı sorulmuş ve öğretmenlerin tamamı $(N=78)$ programın eksik taraflarının olduğunu düşündüklerini ifade etmiştir. Öğretmenlerin 2004 yılında kabul edilen Türkçe Dersi Öğretim Programının güçlü ve zayıf yönleri hakkında ifade etmiş oldukları görüşlerine ilişkin bulgular Tablo 1 ve Tablo 2'de sunulmuştur.

Tablo 1. Sınıf öğretmenlerinin 2004 yılında kabul edilen Türkçe dersi öğretim programının zayıf yönlerine ilişkin görüşleri

\begin{tabular}{lr}
\hline Görüşler & $f$ \\
\hline Okuma parçalarının uygunsuzluğu & 20 \\
Bitişik eğik yazı kullanılması & 18 \\
Dilbilgisi kazanımlarının yetersizliği & 10 \\
Ses temelli cümle yöntemi & 7 \\
Üst düzey etkinliklere az yer verilmesi & 1 \\
Kazanımların içerik olarak yetersizliği & 2 \\
Ses grupları & 1 \\
Açık heceye geçiş öğretimi & 6 \\
Kaynakların dik temel olması & \\
Bitişik eğik yazının üst sınıflarda terkedilmesi & 1 \\
Etkinliklerin karmaşık olması & 3 \\
Ders kitaplarının uygunsuzluğu & 1 \\
Birleştirilmiş sınıf uygulamalarını yansıtmaması & 2 \\
Çok fazla tekrar olması & 4 \\
Bilgim yok & \\
Okuduğunu anlamaya & 6 \\
Okuma hızını yavaşlatması & 11 \\
\hline
\end{tabular}

Tablo 1 incelendiğinde özellikle öğretmenlerin 2004 yılında kabul edilen programda ortaya konulan ses temelli cümle yöntemi ve bitişik eğik yazı öğretimi ile birlikte öğrencilerde okuma hızının 


\section{Sınıf Öğretmenlerinin Türkçe Dersi Öğretim Programına Yönelik Görüşleri}

yavaşladığı, bitişik eğik yazı öğretimine geçilmesinin öğrencilerde yazma becerisini kazandırılmasını yavaşlattığını ve okunaklı yazı yazmada problemlerin oluştuğunu, dilbilgisi kazanımların programda yetersiz kaldığı ve okuduğunu anlamaya yönelik azlığına yönelik bağlamında görüşlerini ifade ettikleri anlaşılmıştır. Aşağıda bu soruya ilişkin öğretmen görüşlerinden örnek alıntılara yer verilmiştir:

"Tümdengelim yöntemi daha hızlı ve anlamlı okuma alışkanlığı kazandırıyordu. Tümevarımda ses, ses birleştirildiği için heceleme yanlış oluyor ve okuma hızı yavaşlıyor. (ÖK3)”

"Tümdengelimde öğrenciler hızlı okuma yapabiliyor, okuduklarını daha rahat anlayabiliyorlardı. Tümevarımda ise hem okuma hızı yavaşlıyor, hem de anlamlandırmada sıkıntı çıkıyor. (ÖK4)”

"Heceleme yaparken öğrenciler yanlış heceliyor, sıkıntı oluyor. Okuma hızı yavaş oluyor. Anlamlandırmada sıkıntı oluyor. (ÖK6)"

"Öğrencilerin okuma hızları yavaş, bitiş̧ik eğik yazıdan dolayı yazılar bozuktur. Harften geldiği için anlamlı okuma yapılamıyor. (ÖK7)”

Tablo 2. Sınıf öğretmenlerinin 2004 yılında kabul edilen Türkçe dersi öğretim programının güçlü yönlerine ilişkin görüşleri

\begin{tabular}{lr}
\hline Görüşler & $f$ \\
\hline Ses temelli cümle yöntemi & 5 \\
Bitişik eğik yazı öğretimi & 2 \\
Okuma ve yazma becerisini kazanmada kolaylık & 1 \\
Öğrenme alanları & 1 \\
Zengin etkinlikler & 1 \\
Kazanımların kapsamı & 1 \\
Öğrenci merkezli & 8 \\
Sezdirme yaklaşımı/dolaylı öğretim & 2 \\
\hline
\end{tabular}

Tablo 2 incelendiğinde programın güçlerine yönelik olarak öğretmenlerin özellikle öğrenci merkezli olması üzerinde durdukları aynı zamanda ses temelli cümle yöntemi uygulamasına geçiş sürecini de olumlu olarak gördükleri yönünde kendilerini ifade ettikleri anlaşılmıştır. Aşağıda buna yönelik öğretmen görüşlerinden örnek alıntılara yer verilmiştir:

"2004 programı ile eğik yazı, dik temel yazıya göre daha hızlı yazılmaktadır. Aynı şekilde eğik yazı öğrencilerin el kasları için uygundur. Daha kısa sürede okumaya başlanmaktadır. Öğrenen merkezli bir program olması da hem öğretmene hem de öğrenciye avantaj sağlamaktadır. (ÖK8)"

"Bu program çerçevesinde öğrenciler daha kısa zamanda okumaya geçebiliyor. Ancak okuma hızı daha yavaş oluyor. (ÖKg)"

"Direk bilgi istemeyip bilgiyi yapılandırması güzel. Bilgiyi ulaşma yollarını araştırması için yollar olması iyi. (ÖE13)"

"Dinleme, konuşma, okuma, yazma, görsel okuma ve görsel sunu olmak üzere beş ana bölüme ayrılan program öğretmene esneklik sağlamaktadır. Bu güçlü bir yön olarak kabul edilebilir. (ÖE14)” 
"Ses temelli cümle yöntemi okuma-yazma öğretiminde faydalı buluyorum. (ÖK29)"

Sınıf Öğretmenlerinin 2004 yılında kabul edilen Türkçe Dersi Öğretim Programının eksikliklerine yönelik önerilerine ilişkin görüşleriyle ilgili bulgular Tablo 3’te sunulmuştur.

Tablo 3. Sınıf öğretmenlerinin 2004 yılında kabul edilen Türkçe dersi öğretim programının eksiklikleriyle ilgili önerilerine yönelik görüşleri

\begin{tabular}{lr}
\hline Görüşler & $f$ \\
\hline Kısa metinler & 16 \\
Harflerin biçimlerinde değişiklik $(r, b, v)$ & 2 \\
Ders kitaplarının program uygunluğu & 8 \\
Farklı etkinlikler & 11 \\
Daha fazla yazma çalışmaları & 1 \\
Kazanımların yeninden yapılandırılması & 1 \\
Cümle yönteminin kullanılması & 4 \\
Açık heceye geçiş & 9 \\
Metinlerin sınıf seviyelerine uygunluğu & 5 \\
Ölçme ve değerlendirmeyi yapılandırma & 1 \\
Strateji öğretimi & 1 \\
Öğrenci merkezli bir program & 1 \\
Birleştirilmiş sınıflara uygunluk & 1 \\
Dilbilgisi çalışmalarının arttııılması & 12 \\
Okuma ve yazmada dik temel harfler & 17 \\
Velilerin farkında olabilecekleri bir program & 1 \\
\hline
\end{tabular}

Tablo 3 incelendiğinde özellikle öğretmenlerin öneriler bağlamında hazırlanan ders kitaplarında daha kısa metinlerin kullanılmasına yönelik görüş ifade ettikleri anlaşımıştır. Buna ek olarak ders kitaplarının program uygunluğunun artırıması, yazma becerisi ile ilgili çalışmalara daha fazla ağırlık verilmesi, metinlerin sınıf seviyelerine uygunluğunun artırılması ve ölçme ve değerlendirmenin yeninden yapılandırıması şeklinde ağırlıklı olarak görüşlerini belirttikleri görülmüştür. Aşağıda buna yönelik öğretmen görüşlerinden örnek alıntılara yer verilmiştir:

“Okuma ve yazmada düz yazıya geçilmesi, güzel yazı ve süsleme için bölüm oluşturulması. (ÖE)”

"En azından 1. sınıfta öğrenciler el yazısına zorlandırılmamalı diye düşüyorum. Dilbilgisine de her hafta yer verilmeli; metinler kısa, bilgi verici, eğlendirici, ilgi çekici olmalı. Ve anlaşılır...(ÖK4)”

"Kullandığımız Türkçe ders kitaplarının içeriği programın amaçlarına ulaşabilmesi açısından yeterli değildir. Bu yönde çalışmalar yapılarak etkinlikler zenginleştirilebilir. Ses temelli yöntemle çocuklar daha erken okuyabilmekte ancak sonraki aşamada okuma hızının artması zaman almaktadır. Bu sorunu giderebilecek çalışmalar yapılabilir. (ÖK8)”

"Bitişik eğik yazıda ısrar edilmemeli. (ÖE10)"

"3. Sınıftan itibaren bitişik eğik yazıyla birlikte düz yazıya geçilmesi gerekir. (ÖE26)”

"Daha dikkat çekici metinler olabilir. Kazanımlar daha dilbilgisi ağırıklı olabilir. Çünkü MEB genelinde yapılan sınavların ve deneme sınavlarının çoğu dilbilgisi ağırıkı. (ÖK39)” 


\section{Sınıf Öğretmenlerinin Türkçe Dersi Öğretim Programına Yönelik Görüşleri}

"I. sınıfta eğik bitişik yazı öğretimi maalesef iyi sonuçlar vermemektedir. Çoğunlukla yazılar bozuk ve kurallardan uzaktır. Zaten çocuk II. kademeye geçtiğinde kullandığı yazıyı bırakmakta bu da yazının daha da bozulmasına sebep oluyor. (ÖK47)"

"Metin seçiminde daha seçici davranılmalı. (ÖK49)"

"Dilbilgisi konuları olmalı. Bitişik eğik yazı kalmalı. Değişen Türkçe Dersi öğretim Programına tüm okulların riayet etmesi ve uygulanan tüm sınavlarda buna uyulması zorunluluğu getirilmeli. (KÖ55)"

"Metinler çok uzun, dikkat çekici değil. Genelde etkinlikler anlaşılmaz. Anlama ve kavramaya yönelik olmadığını düşünüyorum. Özellikle dilbilgisi konuları fazla ve dağınık. Örnekler yetersiz. (EÖ74)”

Sınıf öğretmenlerinin 2016-2017 eğitim ve öğretim yılında uygulamaya konulan yeni Türkçe Öğretim programını inceleyip incelemediklerine ilişkin görüşleri Tablo 4'te sunulmuştur.

Tablo 4. Sınıf öğretmenlerinin 2016-2017 eğitim ve öğretim yılında uygulamaya konulan yeni Türkçe öğretim programını inceleyip incelemediklerine ilişkin görüşleri

\begin{tabular}{lr}
\hline Görüşler & $f$ \\
\hline Evet & 9 \\
Hayır & 68 \\
\hline
\end{tabular}

Yukarıdaki Tablo 4 incelendiğinde öğretmenlerin çoğunluğunun yeni programı okumadıkları anlaşılmaktadır.

Bundan sonraki tablolarda yeni programı incelediklerini ifade eden sınıf öğretmenlerinin görüşleri değerlendirilmiş ve onlara ilişkin bulgular sunulmuştur. Öğretmenlerin 2004 programı ile 2015 programı karşılaştırıldığında nelerin değiştiğine ilişkin görüşleri Tablo 5'te sunulmuştur.

Tablo 5. Sını öğretmenlerinin 2004 Türkçe öğretim programı dikkate alındığında 2015 programında ortaya çıkan değişikliklere ilişkin görüşleri

\begin{tabular}{lc}
\hline Görüşler & $f$ \\
\hline Öğrenme alanları & 4 \\
Harf yazım şekilleri & 5 \\
Ses grupları & 5 \\
Açık hece öğretimi & 1 \\
Alt öğrenme alanları & 1 \\
Kazanım sayısında azaltma & 2 \\
\hline
\end{tabular}

Tablo 5 incelendiğinde öğretmenlerin yeni programda özellikle öğrenme alanlarının, harf yazım şekillerinin ve ses gruplarının değiştiklerini ifade ettikleri görülmüştür. Yine bir öğretmenin açık hece öğretimi ile ilişkili yapılan değişikliği vurguladığı, başka bir öğretmenin alt öğrenme alanlarının oluşturulduğunu ifade ettiği ve yine başka bir öğretmenin de kazanım sayısının azaltıldığını belirttiği görülmüştür. Aşağıda buna yönelik öğretmen görüşlerinden örnek alıntılara yer verilmiştir:

"Türkçe öğrenme alanlarında bir değişiklik yapılmış. Bazı küçük ve büyük harflerin yazımında değişiklikler var. (KÖ8)” 
"Verilen seslerin sıralaması, açık hece oluşturmada, daha fazla hece oluşturmak açısından yararlı olmuştur. Kazanım sayısının azaltılması öğretmene daha geniş bir alan bırakmıştır. (ÖK18).

"Harf grupları değişmiş. Harflerin yazımında değişiklikler olmuş. (Ö47)"

"Okuma öğrenme alanına akıcı okuma ve söz varlığını geliştirme gibi alt öğrenme alanları eklenmiş, sözlü iletişim alanı eklenmiş, harf gruplarının veriliş sırasında bazı harflerin yerleri değişmiş. (ÖK60)”

"Harf sırası, yazılışları, öğrenme alanları. (ÖK65)"

Öğretmenlerin yeni programda yapılan değişiklikleri yeterli görüp görmediklerine ilişkin görüşleri Tablo 6'da sunulmuştur.

Tablo 6. Sınıf öğretmenlerinin yeni programda yapılan değişiklikleri yeterli görüp görmediklerine ilişkin görüşleri

\begin{tabular}{lr}
\hline Görüşler & $f$ \\
\hline Evet & 1 \\
Kısmen & 7 \\
Hayır & 1 \\
\hline
\end{tabular}

Tablodaki öğretmen görüşleri değerlendirildiğinde genel olarak öğretmenlerin programda yapılan değişiklikleri yeterli gördükleri anlaşımaktadır.

Sınıf öğretmenlerinin yeni programın beklentilerini karşılayıp karşılamadığına ilişkin görüşleri Tablo 7'de sunulmuştur.

Tablo 7. Sınıf öğretmenlerinin yeni programın beklentilerini karşılayıp karşılamadığına ilişkin görüşleri

\begin{tabular}{lc}
\hline Görüşler & $f$ \\
\hline Karşılamadı & 4 \\
Dilbilgisi konularının sezdirilerek verilmesi & 1 \\
Öğrenme alanlarındaki değişiklikler olumsuz & 1 \\
Bitiş eğik yazı öğretiminin devam ettirilmesi & 2 \\
İşlenecek metin sayısının fazla olması & 1 \\
Ara sınıfların değişiklikten olumsuz etkilenmesi & 1 \\
\hline
\end{tabular}

Yakarıdaki Tablo 7 incelendiğinde bazı öğretmenlerin programda yapılan değişikliklerin beklentilerini karşılamadığı yönünde kendilerini ifade ettikleri görülmektedir. Genel olarak dilbilgisi konularının sezdirilmesinin, dil öğrenme alanlarında değişikliğe gidilmesinin ve kapsamının daraltılmasının, bitişik eğik yazı öğretimine devam edilmesinin, öğretimi yapılacak metin sayısının arttırımasının ve ara sınıfların yapılan değişiklikten olumsuz etkilenecek olmasının yeni programla ilgili beklentileriyle örtüşmediğini ifade etmişlerdir. Aşağıda buna yönelik öğretmen görüşlerinden örnek alıntılara yer verilmiştir:

"Programda dilbilgisi konuları öğrencilere hissettirilerek veriliyor. Bu husus uygulamada eksikliklere yol açıyor. Soyut konular öğrencilere kazandırılma noktasında yetersi kalıyor. (ÖK18)”

"Öğrenme alanlarındaki değişiklikleri olumlu buluyorum. (ÖE27)" 


\section{Sınıf Öğretmenlerinin Türkçe Dersi Öğretim Programına Yönelik Görüşleri}

"Tam olarak karşılamıyor. El yazısının daha önceden olduğu gibi ikinci sınıfın ikinci yarısından sonra gösterilmeye başlanmalı. 4. sınıftan sonra el yazısı pek kullanılmıyor. (ÖE46)”

"El yazısı sıkıntısı tekrar devam edecek ve bazı harflerin değişmesi ara sınıfları etkileyecek. (ÖK65)"

Sınıf öğretmenlerinin yenilen programdaki öğrenme alanları ile ilgi görüşleri Tablo 8’de verilmiştir.

Tablo 8. Sınıf öğretmenlerinin yeni programda öğrenme alanlarılla ilgili yapılan değişikliklere ilişkin görüşleri

\begin{tabular}{lr}
\hline Görüşler & $f$ \\
\hline Olumlu & 8 \\
Başlık değişse de içerik aynı & 1 \\
\hline
\end{tabular}

Tablo incelendiğinde öğretmenlerin çoğunluğunun programda yapılan öğrenme alanları ile ilgili değişiklikleri olumlu yönde karşıladıkları anlaşılmaktadır. Aşağıda buna yönelik öğretmen görüşlerinden örnek alıntılara yer verilmiştir:

"Yapılan değişikliğe göre sözlü iletişim diğer iptal edilen öğrenme alanındaki kazanımları da içine alıyor. Olumsuz bir sonuç doğuracağını sanmıyorum. (ÖK8)”

"Dinleme-konuşma-okuma ve yazma öğrenme alanları kazanım sayısının da fazla olmasına ve bazı kazanımların tekrarına sebep oluyordu. Azaltılması gerekiyordu. (ÖK18)"

"Sözlü iletişimin eklenmiş olması, çocukların kendisine olan güvenlerini arttıracağına inanıyorum. (ÖK60)"

Sınıf öğretmenlerinin ses temelli cümle yönteminin ve bitişik eğik yazı öğretiminin yeni program da kullanılmaya devam edilmesine yönelik görüşleri Tablo 9'da sunulmuştur.

Tablo 9. Sınıf öğretmenlerinin yeni programda ses temelli cümle yöntemi ve bitişik eğik yazı öğretiminin devam ettirilmesine yönelik görüşleri

\begin{tabular}{lc}
\hline Görüşler & $f$ \\
\hline Devam Ettirilmeli & 4 \\
Dik temel harflerin öğretimi yapıımalı & 8 \\
Ses temelli cümle yöntemi devam etmeli & 6 \\
Cümle yöntemine geçilmeli & 1 \\
Bitişik eğik yazı öğretimindeki eksiklikler giderilmeli & 1 \\
\hline
\end{tabular}

Tablo değerlendirildiğinde öğretmenlerin bazılarının ses temelli cümle yöntemi ile öğretimin devam ettirilmesinin olumlu bir karar olduğu yönünde kendi görüşlerini belirtirken bazı öğretmenler de dik temel harflerin öğretiminin de yapılması gerektiği noktasında kendilerini ifade ettikleri anlaşılmaktadır. Yine dört öğretmen hem ses temelli cümle yönteminin hem de bitişik eğik yazı öğretiminin devam ettirilmesinin olumlu olduğunu, bir öğretmen cümle yöntemine geçilmesi gerektiği ve bir öğretmen de bitişik yazı öğretimindeki eksikliklerin derilmesini savunmuştur. Aşağıda buna yönelik öğretmen görüşlerinden örnek alıntılara yer verilmiştir: 
"Ses temelli cümle yönteminin devam etmesi gerektiği görüşündeyim. Bitişik eğik yazı öğretiminde de eksiklikler gözden geçirilip, aksaklıklar giderilip devam edilebilir. (ÖK8)”

"Ses temelli cümle yöntemi öğrencilerin kısa sürede ses-harf/hece-cümleye geçmelerini ve parçadan bütüne daha rahat öğrenme yaşantılarını sağlıyordu. Devam etmesi bu sebeple gerekli. Lakin bitişik eğik yazı çocuklar için oldukça zor. Dik temel harfler olmalıydı. (ÖK18)”

"Ses temelli öğretimin olumlu olduğunu düşünüyorum. Fakat bitişik eğik yazının olumlu sonuçlar verdiğini düşünmüyorum. (ÖE27)”

"Ses temelli cümle yönteminin devam etmesini istiyorum. Ama bitişik eğik yazı öğretiminin devam etmesini uygun bulmuyorum. Çocuklar ortaokula devam edemiyorlar. Ingilizce dersinde zorluk çekiyorlar. (ÖE46)”

Sınıf öğretmenlerinin yeni programda ses/harf gruplarının değişmesi, bazı harflerin yazımının değişmesi ve açık hece oluşturulmasında değişiklik hakkındaki görüşlerine ilişkin bulgular Tablo 10'da sunulmuştur.

Tablo 10. Sını öğretmenlerinin ses/harf gruplarının değişmesi, bazı harflerin yazımının değişmesi ve açık hece ile ilgili değişikliklere yönelik görüşleri

\begin{tabular}{ll}
\hline Görüşler & $f$ \\
\hline Yazım şekillerinin değişmesi olumlu & 5 \\
Çok farklılık oluşturmadı & 3 \\
Karışıkık oluşturacak olması & 2 \\
\hline
\end{tabular}

Tablo incelendiğinde öğretmenlerin çoğunluğu ses/harf gruplarının değişmesini ve bazı harflerin yazımındaki değişiklikleri iyi yönde yapılan değişiklikler olarak gördükleri anlaşılmaktadır. Aşağıda buna yönelik öğretmen görüşlerinden örnek alıntılara yer verilmiştir:

"Harf gruplarının değişmesi neyi değiştirir çözemedim ancak bazı harflerin yazımının değişmesi yerinde bir değişiklik olmuş. (ÖK8)”

"Daha fazla açık hece oluşturulması kelime hazinesini zenginleştireceğinden harf/ses grubu değişikliğini olumlu bir gelişme olarak buluyorum. (ÖK18)"

"Çok köklü değişiklikler olmadığı için herhangi bir önem teşkil etmiyor. (ÖE27)"

"Bu değişiklikleri doğru buluyorum. Özellikle " $d$ " ve "s" harfinin yazımında öğrenciler zorlanıyordu. Daha iyi olmuş. (Ö4E46)"

"Harflerin öğretim grupları çok değişmiş. "B" sesi gibi çok kolay çıkmayan bir sesin ön gruba gelmesi, " $M$ " sesinin çok geri bir gruba gitmesi çok olumlu değil. Deneyip göreceğiz. " $D$ " sesinin yazılışı uygun. (ÖK47)" 


\section{Sınıf Öğretmenlerinin Türkçe Dersi Öğretim Programına Yönelik Görüşleri}

Sınıf öğretmenlerinin eski programla karşılaştırıldığında yeni programda sınıf düzeylerine göre metin ve tema sayısının artırılması konusuna yönelik görüşleri Tablo 11'de sunulmuştur.

Tablo 11. Sınıf öğretmenlerinin eski programla karşılaştıııldığında yeni programda sınıf düzeylerine göre metin ve tema sayısının arttırılması konusuna yönelik görüşleri

\begin{tabular}{lr}
\hline Görüşler & $f$ \\
\hline Arttıııması olumlu & 7 \\
Arttırılması olumsuz & 2 \\
\hline
\end{tabular}

Tablo incelendiğinde öğretmenlerin çoğunluğunun metin ve tema sayısında olumlu yönde karşıladıkları anlaşılmaktadır. Aşağıda buna yönelik öğretmen görüşlerinden örnek alıntılara yer verilmiştir:

"Sınıf düzeyi arttıkça metinlerin de artması, içeriğin genişlemesi amaca ulaşabilmek için yararlı olacaktır diye düşünüyorum. (ÖK8)"

"Her metnin işlenmesi yıl içerisinde mümkün olmuyor. Metin sayısının artması çeşitliliği bu sebeple de seçim sayısını arttırmış olduğundan gereklidir. (ÖK18)"

"Metin ve tema konularının artırımı bence iyi ama metinleri ve içeriklerini görmemiz gerekir. Metinler basit ve öğrenci seviyelerine uygun olmalı. Çok fazla etkinliğe yer verilmeli. (ÖE46)"

"Yeni temaların eklenmesi çocukların bakış açılarını değiştirebilir. (ÖK60)"

"Bu iyi olmuş. (ÖK65)"

Sınıf öğretmenlerinin eski programla karşılaştıııldığında yeni programın içerik açısından öğretmenlere yönelik daha az rehberlik edecek bir içeriğe sahip olması konusundaki görüşlerine ilişkin bulgular Tablo 12'de sunulmuştur.

Tablo 12. Eski programla karşılaştırıldığında yeni programın içerik açısından öğretmenlere yönelik daha az rehberlik edecek bir içeriğe sahip olup olmadığı konusunda öğretmen görüşleri

\begin{tabular}{ll}
\hline Görüşler & $f$ \\
\hline Öğretmene esneklik tanıması & 3 \\
Daha fazla rehberlik etmeli & 1 \\
Öğretmenlere güvenmeleri & 1 \\
Öğretmeni araştırmaya yönlendirme & 4 \\
\hline
\end{tabular}

Tablo incelendiğinde bazı öğretmenler yeni programda öğretmene rehberlik edecek daha az bir içerik sunulmasının öğretmenlere esneklik tanıyacağını ve öğretmeni daha fazla araştırmaya yönlendireceğini ifade ederken bir öğretmen bu bağlamda öğretmenlere güvenmeleri gerektiğini ve yine bir öğretmen de daha fazla rehberlik edilmeli şeklinde görüşlerini ifade etmiştir. Aşağıda buna yönelik öğretmen görüşlerinden örnek alıntılara yer verilmiştir:

"Yeni atananalar zaten yaparak yaşayarak öğreniyor. Aynen devam eder. (ÖK65)" 
"Hazır şeylerin öğretmenin yaratıcılığını düşürdügünü düşünüyorum. Bu şekilde olması öğretmenin araştırmaya yönlendireceğini düşünüyorum. Öğretmen biraz yaratıcı olmalı bence. (ÖK60)”

"Demek ki öğretmenlerin yetenek ve becerilerine güveniyorlar. (ÖK47)"

"Bu programa göre öğretmenler daha çabuk bir biçimde çok fazla rehberliğe gerek duymadan durumu kavrayarak en verimli şekilde programı uygulayacaklarını düşünüyorum. (ÖE46).

"Daha fazla rehberlik edici olması gerekiyor. (ÖK20)"

"Öğretmenlere bireysel farkılıklarını uygulayacağı daha fazla alan verilmiş. (ÖK18)"

\section{Tartışma}

Bu araştırmada sınıf öğretmenlerinin 2016-2017 eğitim ve öğretim yılında uygulama konulan Türkçe Dersi Öğretim Programına yönelik görüşleri elde edilmiştir. Çalışma toplam 78 sınıf öğretmeni gerçekleştirilmiştir. Araştırmaya katılan sınıf öğretmenlerinin çoğunluğu yeni programı incelemediğinden anket formundaki yeni program ile ilgili bazı sorular toplam sadece dokuz sınıf öğretmeni tarafından cevaplanmıştır ve dolayısı ile bu soruların analizi toplam dokuz sınıf öğretmeni üzerinden gerçekleştirilmiştir.

Elde edilen veriler üzerinde ulaşılan sonuçlar çalışma grubundaki deneyimli öğretmenlerin yeni programda ses temelli ve bitişik eğik yazı ile okuma ve yazma eğitiminin gerçekleştirilmeye devam etmesinin yanlış olduğunu, bunu yerine cümle yöntemi ile okuma becerisinin ve dik temel harflerle de yazma becerisinin kazandırılması yönünde görüşlerini ifade ettikleri anlaşılmıştır. Bunun yanında araştırma bulguları değerlendirildiğinde çalışmaya katılan öğretmenlerini çoğunluğunun yeni programı incelemediği görülmüştür. Programı inceleyenlerin sadece deneyimi daha az olan öğretmenlerin olması araştırmanın şaşırtıcı sonuçlarından birisi olarak gösterilebilir. Araştırmanın bulguları göz önünde bulundurulduğunda araştırmaya katılan öğretmenlerin çoğunluğunun kendilerine yönlendirilen sorularda özellikle yeni programla ilgili değişkenlere yönelik görüşleri sorulmasına rağmen öğretmenlerin görüşlerini ve eleştirilerini daha çok program ekseninde geliştirilen ders kaynaklarına yönlendirdikleri görülmüştür. Deneyimli öğretmenlerin, mesleki kıdemi fazla olanların, deneyimsiz öğretmenlerle, mesleki deneyimi daha az olan öğretmenlerle, kıyaslandığında yeni program yönelik daha fazla olumsuz yönde eleştiri yaptığı anlaşılmıştır. Araştırmadan elde edilen diğer bir sonuç olarak ise çalışmaya katılan öğretmenlerin dilbilgisi konuları ile ilgili doğrudan öğretim yapılması, sezdirilerek verilmemesi ve dilbilgisi kazanımlarının sayısının artırılması noktasında kendilerini ifade etmeleridir. Buna sebep olarak ise temel eğitimden ortaöğretime geçişte gerçekleştirilen ortak sınavlarda (TEOG) sorulan soruların bir neden olabileceği düşünülmektedir. Çünkü ülkemizde ulusal düzeyde yapılan sınavlarla ilgili en büyük eleştirilerden biri olarak sınavlarda öğrencilere yönlendirilen soruların hem öğretmenlerin sınıf içi uygulamalarını hem de öğretim 


\section{Sınıf Öğretmenlerinin Türkçe Dersi Öğretim Programına Yönelik Görüşleri}

programlarını yansıtmadığı gösterilmektedir. Buna ek olarak bazı araştırmalarda bu sınavlarda kapsam geçerliliği sorunları yaşandığı belirtilmiştir (örn., Cayhan, 2015; Karadeniz, Eker ve Ulusoy, 2015; Koğar ve Aygun, 2015). Benzer şekilde Kırmızı ve Akkaya (2009) tarafından 2005 yılında uygulamaya konulan Türkçe Dersi Öğretim Programı ile ilgili yapılan araştırmada da öğretmenlerin çoğunluğu dilbilgisi konularının azaltılmasına ve dilbilgisi konularının sezdirilerek verilmesine olumlu olarak yaklaşırken bazı öğretmenler de SBS gibi sınavlar göz önünde bulundurulduğunda dilbilgisi konularının azaltılmaması gerektiğini ifade etmişlerdir. Bu araştırmada da böyle bir kaygı yani uygulamadaki program, ders kaynakları, öğretimsel süreçler ve sınavlar bağlamında oluşacak tutarsızlık öğretmenlerin dilbilgisi konularının öğretimi konusunda görüşlerini farklılaştırmış olabilir.

Araştırma sonuçları çalışmaya katılan öğretmenlerin yeni programın içerik anlamında öğretmenlere daha az rehberlik etmesini, tema ve metin sayısının artırılmasını, açık hece oluşturma, ses grupları ve bazı harflerin yazım şekillerindeki değişiklikleri, öğrenme alanlarının sayısının azaltıımasını olumlu karşıladıklarını ortaya koymasına rağmen çalışmadaki öğretmenlerin genel olarak Türkçe Dersi Öğretim Programındaki değişiklikleri yeterli görmediklerini ortaya koymuştur. Aynı zamanda yapılan değişikliklerin öğretmenlerin beklentilerini tam olarak karşılamadığı anlaşılmıştır.

Yukarıda da ifade edildiği çalışmaya katılan sınıf öğretmenlerinden mesleki kıdemi daha fazla olan sınıf öğretmenlerinin yeni programı okumadıkları ve yeni programla ilgili farkındalıklarının çok az olduğu anlaşılmıştır. Bu durumun farklı nedenleri olabileceği düşünülmektedir. Bu sebeplerden biri olarak deneyimle birlikte öğretmenlerde tükenmişliğin artması ve öğretmenlerin kendilerini geliştirme çabalarıın azalması gösterilebilir. Öğretmenlerin karakteristik özelliklerini anlayabilme, eğitim ve öğretim ortamında ortaya çıkan birçok problemin nedenlerini belirleyebilmek noktasında çok fazla katkı sunmaktadır. Öğretmen tükenmişliği Freudenberger (1974, akt. Talmor, Reiter ve Feign, 2005) tarafından fiziksel veya mental olarak hissedilen yorgunluk, hüzün ve yalnızlık olarak ifade edilmektedir. Stres ve tükenmişlik öğretmenin kararlarını etkileyen en önemli değişkenlerden bazıları olarak ifade edilmektedir. Tükenmişliği yaşayan öğretmenlerde duygusal yorgunluk, kendini negatif değerlendirme ve olumsuz yönde eleştirme, çalışma arkadaşlarına yönelik negatif tutum vb. durumların görüldüğü belirtilmektedir (Egyed ve Short, 2006). Yine benzer şekilde tükenmişlik yaşayan öğretmenlerde fiziksel, mental ve davranışsal yorgunlukların oluştuğu, mesleki memnuniyetsizlik ve başkalarını suçlama semptomların da görüldüğü belirtilmiştir. Buna ek olarak mesleki kıdemle birlikte yani öğretmenlik deneyiminin artması ile birlikte öğretmen tükenmişliğinde de artışların olabileceği bunun da öğretmenler de öğrencilere yönelik katı tutumlar geliştirmeye, öğrencilere karşı olumsuz tutumlara sahip olmaya, öğrencilerle ilgili daha düşük beklentiler oluşturmaya ve yeniliklere açık olmamaya ve kendini geliştirmek için daha az çaba göstermeye neden olabileceği ifade edilmiştir (Farber ve Miller, 1981). Öğretmenlik deneyimi ön yaşantılarla ilgili değişkenler arasında gösterilip 
öğretmenlik tükenmişliği etkileyen en önemli faktörlerden biri olarak gösterilmektedir (Talmor, Reiter ve Feigin, 2005). Dolayısı ile bu çalışmada da öğretmenlik deneyimiyle ortaya çıkan tükenmişlik probleminin öğretmenlerin yeni programı incelemelerini ve bu bağlamda kendi farkındalıklarını arttırmalarını engellemiş olabileceği düşünülmektedir.

Öğretmenlerin yeni programı okumamalarının başka bir nedenin ise öğretmenlik deneyimine yani mesleki kıdeme bağlı olarak ortaya çıkan öğretmenlik öz yeterlilik inançları gösterilebilir. Çalışmaya katılan deneyimli öğretmenlerin daha zayıf düzeyde öz yeterlilik inançlarından kaynaklı olarak yeni programı okumadıkları varsayılmaktadır. Öğretmen öz yeterliliği ve öğretmen deneyimi arasındaki ilişkileri inceleyen bilimsel araştırmaların sonuçları çok fazla tutarlılık göstermemesine rağmen bu çalışmaların bazılarında deneyimle öz yeterlilik arasında negatif düzeyde ilişkiler olduğu bulunmuştur (örn., Ghaith ve Yaghi, 1997; Hoy ve Spero, 2005; Klassen ve Chiu, 2010; Ross, Cousins ve Gadalla, 1996). Öğretmen öz yeterliliğinin öğretmenlerin öğretim davranışlarını, kendilerini geliştirmelerini, öğrencilerinin motivasyonlarını ve başarılarını etkilediği göz önünde bulundurulduğunda çalışmaya katılan sınıf öğretmenlerinin düşük düzeyde öz yeterliliğe sahip olmaları yeni programa yönelik farkındalıklarını artırma çabalarını olumsuz etkilemiş olabilir.

\section{Araştırmanın Sınırlılıkları ve Yapılacak Araştırmalara yönelik Öneriler}

Araştırmada toplam 78 öğretmenle çalışılmıştır. Ancak öğretmenlerin büyük bir çoğunluğu yeni programı incelemiş olmadığından anket formundaki bazı sorular sadece dokuz sınıf öğretmeni tarafından cevaplanmıştır. Bu durumun araştırmanın zengin bir veri seti sunma amacını olumsuz yönde etkilemiş olabileceği ifade edilebilir. Yapılacak benzer çalışmalarda daha fazla katılımcı sayısına ulaşılarak elde edilecek verilerin geçerliliği ve güvenirliliği artırılabilir. Anket formunda yer alan açık uçlu ve kapalı uçlu soruların tamamı eski ve yeni programla ilişkili olmasına rağmen bazı öğretmenlerin soruları ders kaynaklarını (ders kitabı, çalışma kitabı ve kılavuz kitap) esas alarak cevapladıkları ve görüşlerini programdan çok ders kaynaklarının bir eleştirisi olarak yansıttıkları görülmüştür. Bu durumun nedenleri olarak öğretmenlerin programı incelemedikleri ve öğretimsel uygulamalarını sadece ders kaynaklarını esas alarak yürüttükleri bundan dolayı da programa yönelik soruları ders kaynakları bağlamında cevapladıkları, diğer bir neden olarak ise öğretmenlerin anketteki soruları anlamamış olma intimalleri gösterilebilir. Bundan sonraki araştırmalarda anketteki soruların hazırlanması üzerinde önemle durularak sorulardan kaynaklı oluşabilecek yanlış anlaşımalar ortadan kaldırılabilir. Bu araştırmada veriler sadece hazırlanan anket formu ile öğretmenlerden toplanmıştır. Sonraki araştırmalarda öğretmenlerin sınıf içi uygulamaları da gözlemlenerek öğretim süreçlerinde öğretmenlerin gerçekleştirmiş oldukları çalışmaların ve etkinliklerin öğretim programlarıyla uyumluluğu araştırılabilir. 


\section{Sınıf Öğretmenlerinin Türkçe Dersi Öğretim Programına Yönelik Görüşleri}

\section{Sonuç}

Bir toplumdaki eğitim sisteminin başarısını etkileyen en önemli değişkenlerden biri olarak öğretim programları gösterilebilir. Öğretim programları toplumun ihtiyaç duyduğu insan profilinin yetiştirilmesine önemli katkılar sağlamaktadır. Tabi ki burada bu süreci etkileyen diğer önemli bir faktör ise öğretmen olarak ifade edilebilir. Çünkü sisteminiz ne olursa olsun farkı oluşturan sahip olduğunuz öğretmen niteliğidir. Buradan hareketle hazırlamış olduğunuz öğretim programının niteliği ne olursa olsun öğretim ortamlarında onun asıl uygulayıcıları olan öğretmenlere büyük görevler düşmektedir. Hazırlanan öğretim programının öğretmen tarafından algılanması ve sınıf içi uygulamalara doğru bir şekilde yansıtılması toplumun ihtiyaç duyduğu insan profilinin yetiştirilmesi açısından önem arz etmektedir. Bu araştırmanın ortaya koymuş olduğu bulguların ve bağlamında ifade edilen bilimsel tartışmanın öğretmen ve öğretim programı etkileşiminin öneminin daha iyi anlaşımasına katkı sağlayacağı umulmaktadır.

\section{Kaynaklar}

Cayhan, C. (2015). TEOG sınavı Türkçe dersi sorularının Türkçe dersi öğretim programındaki kazanımlar açısından değerlendirilmesi. Siirt Sosyal Bilimler Enstitüsü Dergisi, 5, 106-114.

Cheung, D. ve Wong, H-W. (2002). Measuring teacher beliefs about alternative curriculum designs. The Curriculum Journal, 13, 225-248.

Cornett, J.W. (1990). Teacher thinking about curriculum and instruction: A case study of a secondary social studies teacher. Theory and Research in Social Studies, 3, 248-273.

Creswell, J. W. (2005). Educational research: Planning, conducting, and evaluating quantitative and qualitative research (2nd ed.). Upper Saddle River, NJ: Pearson Education, Inc.

Çoşkun, E. ve Taş, S. (2008). Ders kitaplarında metin seçimi açııından Türkçe öğretim programlarının değerlendirilmesi. Mustafa Kemal Üniversitesi Sosyal Bilimler Enstitü Dergisi, 5, 59-74.

Davis, E.A. ve Krajcik, J.S. (2005). Designing educative curriculum materials to promote teaching learning. Educational Researcher, 3, 3-14.

Durukan, E. (2013). Öğretmen görüşleri açısından Türkçe dersi öğretim programı kazanımları. Karadeniz Sosyal Bilimler Dergisi, 5, 1-15. ,

Egyed, C. J. ve Short, R. J. (2006). Teacher self-efficacy, burnout, experience and decision to refer a disruptive student. School Psychology International, 27(4), 462-474.

Farber, B. A. ve Miller, J. (1981) Teacher burnout: A psycho-educational perspective. Teachers College Record, $83,235-244$.

Ghaith, G. ve Yaghi, H. (1997). Relationships among experience, teacher efficacy, and attitudes toward the implementation of instructional innovation. Teaching and Teacher Education, 13, 451- 458.

Gömleksiz, M.N., Sinan, A.T. ve Demir, S. (2010). illköğretim Türkçe dersi öğretim programındaki yazma öğrenme alanının etkililiğinin değerlendirilmesi. Turkish Studies, 5, 1135-1173.

Güven, A.Z. (2011). Illköğretim II. kademe Türkçe dersi öğretim programına ilişkin öğretmen görüşleri. Buca Eğitim Fakültesi Dergisi, 29, 121-133.

Güzel, A. ve Karadağ, Ö. (2013). Anlatma becerileri açııından “Türkçe Dersi Öğretim Programı (6,7,8. Sınıflar)”na eleştirel bir bakış. Ana Dili Eğitimi Dergisi, 1, 45-52. 
Jenkins, S.B. (2009). Measuring teacher beliefs about curriculum orientations using the modified-curriculum orientations inventory. The Curriculum Journal, 20, 103-120.

Karadağ, Ö. (2012). Anlama becerileri açısından Türkçe dersi öğretim programı (6,7,8. Sınıflar)’na eleştirel bir bakış. CÜ Sosyal Bilimler Dergisi, 36, 97-110.

Karadeniz, O., Eker, C. ve Ulusoy, M. (2015). TEOG sınavındaki T.C. Inkılap Tarihi ve Atatürkçülük dersine ait soruların kazanım temelli olarak değerlendirilmesi. Uluslararası Avrasya Sosyal Bilimler Dergisi, 6, 115134.

Kırmızı, F.S. ve Akkaya, N. (2009). Türkçe öğretim programında yaşanan sorunlara ilişkin öğretmen görüşleri. Pamukkale Üniversitesi Eğitim Fakültesi Dergisi, 25, 42-54.

Klassen, R. M., ve Chiu, M. M. (2010). Effects on teachers' self-efficacy and job satisfaction: Teacher gender, years of experience, and job stress. Journal of Educational Psychology, 102(3), 741-756.

Koğar, E.Y. ve Aygun, B. (2015). Temel eğitimden orta öğretime geçiş sınavı (TEOG)'nın Matematik temal alanına ait testlerin kapsam geçerliğinin incelenmesi. Pegem Eğitim ve Öğretim Dergisi, 5, 667-680.

Korkmaz, ì. (2006). Yeni ilköğretim birinci sınıf programının öğretmenler tarafından değerlendirilmesi. Selçuk Üniversitesi Sosyal Bilimler Enstitüsü Dergisi, 16, 419-431.

Melanlıoğlu, D. (2008). Kültür aktarımı açısından Türkçe öğretim programları. Eğitim ve Bilim, 33, 64-73.

Pintó, R. (2005). Introducing curriculum innovations in science: Identifying teachers' transformations and the design of related teacher education. Science Education, 89, 1-12.

Ross, J. A., Cousins, J. B. ve Gadalla, T. (1996). Within-teacher predictors of teacher efficacy. Teaching and Teacher Education, 12, 385- 400.

Şahin, I. (2007). Yeni ilköğretim 1. kademe Türkçe programının değerlendirilmesi. Illköğretim Online, 6, 284-304.

Talim ve Terbiye Kuruluğu Başkanlığı. (2017, Şubat 20). Öğretim programları. http://ttkb.meb.gov.tr/www/ogretim-programlari/icerik/72 sitesinden ulaşılmıştır.

Talmor, R., Reiter*, S. ve Feigin, N. (2005). Factors relating to regular education teacher burnout in inclusive education. European Journal of Special Needs Education, 20(2), 215-229.

Woolfolk Hoy, A. ve Burke Spero, R. (2005). Changes in teacher efficacy during the early years of teaching: A comparison of four measures. Teaching and Teacher Education, 21, 343-356.

Yıldırım, K. (2010). Raising the quality in qualitative research. Elementary Education Online, 9(1), 79-92. 